\title{
The Familiarity of Internet Slang among EFL Female \\ Learners in Saudi Arabia
}

\author{
Enas Abdelwahab Eltom RahmtAllah \\ English Department \\ College of Sciences and Arts, Unaizah \\ P. O. Box 5380 \\ Qassim University, Saudi Arabia
}

Received: June 17, 2020 Accepted: July 5, 2020 Published: July 7, 2020

doi:10.5296/ijele.v8i2.17332 URL: https://doi.org/10.5296/ijele.v8i2.17332

\begin{abstract}
The knowledge of Internet slang is essential for English language learners who aim to achieve native-like fluency. This study investigated the familiarity of internet slang among EFL female learners in Saudi Arabia. The study aimed explicitly to examine to what extent EFL female learners are familiar with the Internet slang? Besides, what does the students' knowledge of slang reflect? To achieve these objectives, a total of 71 Saudi female undergraduate English majors at Unaizah College of Sciences and Arts participated in the study. The students were given a test of Internet slang. The data were analyzed through SPSS. The study results demonstrated that the learners' knowledge of Internet slang was moderately limited, and they are not familiar with internet slang. The results also revealed that some acronyms and abbreviations are popular among learners because of the learners' exposure to social media. In light of these results, recommendations are presented.
\end{abstract}

Keywords: Slang, Internet, abbreviation, acronym, EFL 


\section{Introduction}

The new communication technologies and emerging media cultures profoundly affected the world; technological advances have demonstrated a dramatic shift in how individuals communicate (Adams, 2013). Kern (2006) mentions that rapid evolution of communication technologies has changed language pedagogy and language use, enabling new forms of discourse, new types of authorship, and new ways to create and participate in communities. Nowadays, internet communication is an essential and valuable part of life whether the user is nineteen or ninety, a teacher or an engineer, the internet is all over society. It has dramatically changed how people communicate and use English in both writing and speech. As a result, the environment has become increasingly interconnected through synchronous and asynchronous messaging scripts such as text messages, online chat, messengers, emails, etc. Applications like Facebook, Instagram, Twitter, and WhatsApp may also reveal changes that have recently occurred in English. The internet has given rise to what is essentially a new English variety, which is distinct from traditional types (Al-Kadi and Ahmed, 2018). The spreading of Internet communication has come up to every level of society, every profession, age, and gender. Nowadays, a significant number of philological work is dedicated to understanding and analyzing correspondence and more to live communication through the internet, which is easily accessible due to various modern principles that clearly illustrate the high degree of technological advancement. (Zabotnova, 2017). Al Kadi and Ahmed (2018) mention that English spelling, pronunciation, vocabulary, and grammar have changed since the internet became publicly available, resulting in conflicting views and debate among language researchers and pundits. Crystal (2011) argues that these developments in English form and use have created a new linguistic branch he calls Internet Linguistics. He added that as a society and economy continue to grow, internet slang has moved from a form of communication to a language of daily use. People's communicative behavior, style, and psychology have all been affected by the subtle influence of internet slang. Corporations have also started employing internet slang in public communications. The more we communicate on the internet, the more users influence the languages of other countries, and the more these changes affect us because they live communication has a significant impact on language development. Amidst the continuous changing happening to the English language, Namvar and Ibrahim (2014) mention that slang is becoming more and more an essential part of our shifting linguistic terrain. Most new words come from slang. Zabotnova (2017) add that English has become the language of the computer and the internet and students need to be familiar with contemporary English, and slang will be a significant part of this.

Slang is a collection of language- colloquial words or expressions. Slang is the use of terms and phrases of high informality that are not considered standard in the dialect or language of the speaker. Slangs are unique to literature and culture but also transferred from one culture and language to another. Recent electronic communications make a significant contribution to this process (Namvar and Ibrahim, 2014). Abbreviations and acronyms are parts of the Internet slang. According to the Cambridge dictionary, an abbreviation is "a short form of a word or phrase." At the same time, an acronym is "an abbreviation consisting of the first letters of each word in the name of something, pronounced as a word" (https://dictionary.cam- 
bridge.org/). Merriam Webster defines the word abbreviation as "a shortened form of a written word or phrase used in place of the whole word or phrase" Whereas, acronym as:

"a word (such as NATO, radar, or laser) formed from the initial letter or letters of each of the successive parts or major parts of a compound term also: an abbreviation (such as FBI) formed from initial letters: INITIALISM" (https://www.merriam-webster.com/)

\begin{abstract}
Abbreviations and acronyms are interchanged, but the two are very distinct. The critical point of reference is that, while acronyms form new words, abbreviations are merely a sequence of letters.

Nowadays, Internet communication enlists thousands of acronyms and abbreviations. Tomah (2018) calls those acronyms and abbreviations "Cyber slang." He states that

"Cyber slang is a term used to describe shortcuts, alternative words, or even symbols used to convey thoughts in an electronic document. Because so many digital media limit the number of characters an author can use at a time, students are becoming more creative to get the most out of their limited space. Common cyber-slang terms that have made their way into popular speech include BFF (best friends forever), LOL (laugh out loud), and WTF (what the)." (https://lifelearners.ng/effect-of-slang-on-students-language-and-writing/)
\end{abstract}

Some acronyms and abbreviations are more popular widely used as well as others are limited in use due to their professional, age, skills, gender, and other specificities, which play not the last role in Internet communication. For instance, most Internet users from all over the world are familiar with such acronyms as LOL (Laugh Out Loud), OMG (Oh My God), CU (See You), and many others. The underlying meaning for these acronyms, which has already come to life in live oral communication, is based on the desire to show speakers' emotions on the publication or situation. Zabotnova (2017) stresses the importance of a context understanding and adequate interpreting due to the cases when some acronyms, as well as abbreviations, have more than one meaning, which can be entirely lexically opposite to the needed one. It presents not only examples and variants of possible acronyms and abbreviations but also highlights the transformations that have had a place due to language development. For instance, ASH may have completely different meanings- "As hell," "A Safe Haven," "After School Hangout," "Abnormality of Skin and Hair," and many others. Another interesting example is the acronym "OTL." The meaning of this acronym is debatable. To some, the meaning is "one true love." To others, the meaning is "out to lunch." Still, some people assume that the term reflects great sorrow as they look like a person weeping on their hands 
and knees when the letters "OTL" are typed in together. Therefore, it is crucial to keep in mind that the definition of acronyms and abbreviations that are being conveyed often needs to be determined by the context it is being used in. In addition, some acronyms are formed with the help of numerals. Numeral acronyms became a part of words and entered the Internet slang on the new level of communication, these numbers contain their sounding form as well as a written one, but in connection with the letters, they create new units. For instance, 2 as to/too - 2morrow (tomorrow), B2W (back to work), 2BH (to be honest) and many others, 8 as eight -8 (ate), L8R (later); some acronyms contain even symbols, for instance - ?4U (question for you) as in the sentence: "It's my?4U".

The present study aims to investigate whether EFL female learners in Saudi Arabia are familiar with Internet slang, abbreviations and acronyms. Specifically, the study aims at providing data-supported answers to the following research questions:

- To what extent EFL female learners are familiar with the internet sang?

- What does the students' knowledge of slang reflect?

\section{Literature Review}

Slang tends to be specific to a particular territory, and it is a central part of young's experience, but contrary to many adults' perception of slang as more or less uniform "Youth language." Gomaa (2015) conducted a sociolinguistic investigation of Saudi youth slang. The study analyzes the social factors influencing the use of slang. Besides, it sheds light on the sources from which Saudi youth acquire new slang expressions and the reasons for using them. The study concludes that age and Saudi youth slang are negatively correlated. That is, the younger a person is, the higher the level of his/her acquaintance of slang. This informal language, slang, has developed a unique style that requires new terminology, which separates it from daily communication. It is widespread between Internet users, bloggers, chatter, gamers, and teenagers in general. Linguists, educators, and language teachers should take care of this new trend. It has some influences on the formal language and academic writing (Alshlowiy, 2014). Alshawi (2018) carried out a study to examine the relationship between learners' receptive and productive knowledge of American English slang and their university level and integrative motivation. The study results demonstrated that learners' knowledge of American English slang was moderately limited. Learners' receptive knowledge of American English slang was better than their productive knowledge. Furthermore, their integrative motivation level was moderately high. Moreover, no effect of university level on the students' knowledge of American English slang was found. With regard to integrative motivation, no correlation was found between the students' overall integrative motivation and their knowledge of American English slang. In Bulgaria, Charkove (2007) investigated the acquisition of English slang in a foreign language context. The participants of this study were 101 Bulgarian learners of English, 58 high school students, and 43 university students. The students showed a significantly higher appreciation of slang as a way of group belonging and projecting an image of looking cool. Generally, there were quantitative and qualitative differences between 
the age groups on all variables of interest; the researcher interpreted these differences given sociopsychological factors. Namvar and Ibrahim (2014) researched whether young Malaysians use English slang in their language. The two primary objectives of their study were to illustrate to what degree Malaysian youth use English slang and to examine what kind of slang Malaysian youth use more in comparison with other types of slang. A test consists of 20 slang items was administered to 60 students. The respondents were in the final semester of bachelor of English language at University Putra Malaysia. The analysis of data showed that the internet slang, abbreviations slang, and movie slang are used frequently by youth. It seems that Malaysian youth are familiar with these sorts of slangs. Namvar and Ibrahim (2014) note that the reasons for using the internet and social media nowadays may be another factor that has the most critical position in this case. Mazer \& Hunt (2008) examined students' impressions of the use of positive slang (e.g., "cool," "awesome," "sweet") by educator and its perceived effect on the classroom atmosphere and the reputation of teachers, as well as the rules regulating their use. Participants watched a video of a successful slang-using instructor and then answered multiple open-ended questionnaires. The findings indicate that students typically support the use of meaningful slang by teachers and cite the possible advantages of using it. Kadir, Maros, and Hamid (2012) studied the linguistic features used in a discussion forum among the e-distance learning students in 2009 in the University Teknologi MARA Malaysia . The study analyzed 110 messages posted by students to their friends and lecturers. The study found patterns that the participants used in their online words included shortenings, contractions, acronyms and initialisms, letter/number homophones, accent stylization particular pronunciation, speech, and non-alphabetic symbol. The participants also used emoticons, nonconventional spellings, and clippings. Abu Sa'aleek (2015) analyzed 340 messages collected from 160 undergraduate students' e-discourse in the Department of English Language and Translation, in the Unaizah Community College and the Arts and Science College at Qassim University in Saudi Arabia. Similar to the study by Kadir et al. (2012). Abu Sa'aleek's (2015, p. 138) review was an analysis of the linguistic features of electronic discourse. The study categorized the features as follows:

-Shortening

-Clippings

-Contractions

-Unconventional Spellings

-Word-Letter Replacement

-Word-Digits Replacement

-Word Combination

-Initialisms

- Emoticons

Wei (2010) states that Internet slangs are widely used online in China since computer 
technology spreads. Online users from specific "virtual communities" may create, borrow, use, and spread internet slang in terms of particular fields. Mokhsin, Aziz, HamidiLokman, \& Halim (2016) mention that the usage of abbreviation and homophone words among youth is worrying since this situation gives impacts to the kid when writing in the assignments or even test. Mokhsin et al. (2016) investigated the factors that lead youth using abbreviations and homophone words while writing in social networking. Besides, their study also attempts to describe the impacts resulting from the usage of abbreviation and homophone words in social networking. The findings of the study showed the factor that contributes to the use of abbreviation and homophone words is simplicity, which means that type of terms are elementary to use while writing in social networking. The understanding of the factors and impacts from the use of abbreviation and homophone in writing will give awareness and conscious to the youth regarding the usage of abbreviation and homophone words as well as to provide clear distinction between the cyber world and reality in the usage of proper writing communication. A study, by Pradianti (2013), entitled "The Use of Slang Words among Junior High School Students in Everyday Conversation." aims to investigate slang words used by the ninth grade students. The study investigates the morphological processes involved in slang words and the reasons why the students use them in their everyday talk, too. The findings reveal that this study contains 11 groups of morphological processes. Coinage is the most commonly used with $30,56 \%$, followed by $20,14 \%$ blending and $13,19 \%$ borrowing. In addition, there are some factors that affect the use of slang words, namely that students want to express things in a simple way, display their frustration, make others confused, and want fun and laugh. Therefore, it is recommended that future researchers perform studies on various slang users in different settings because slang shifts and rises over time. Gomaa (2015) mentions that contrary to the situation in many countries, where research and projects on youth slang are popular, Saudi Arabia is destitute of systematic records and analysis of this linguistic phenomenon. Such challenging issues motivated us to focus our current study on investigating Familiarity of Internet slang among EFL female learners in Saudi Arabia.

\section{Method}

The methodology of this study is a combination of quantitative and qualitative analysis. In this study, a pilot-test was used to establish the validity and reliability of the instrument. While validity refers to whether or not an instrument measures, what it is supposed to measure, reliability refers to how consistently the instrument yields the same results over repeated trials. The pilot testing helped to determine if the respondents straightforward and easily understand the test. In the test, both correct and incorrect answers were important to researcher. Because the correct answers tell the researcher that students are familiar with slang and incorrect, answers mention that students are not familiar with this slang. The test consisted of 48 items. Slang items for this study were collected from five online websites. They are https://www.magiquiz.com/quiz/how-well-do-you-know-internet-slang/2/,http://home.bt.com/ tech-gadgets/internet/social-media/quiz-how-well-do-you-know-internet-slang-113641354272 $\underline{01}$ 


\section{Macrothink}

https://www.theguardian.com/technology/quiz/2014/aug/07/quiz-internet-slang-bae-how-wellyolo-tbt-mean , https://www.businessinsider.com/internet-slang-quiz-2013-11 and https://www.buzzfeed.com/evelinamedina/how-old-are-you-based-on-your-slang. After that the selected items were checked by three university teachers to be sure about the appropriateness of the slangs and their meaning. The pilot study was administered to 10 students (later those students were excluded from the final sample) 4 students from level eight and 6 from level seven. All of them were students at English Department, College of Sciences and Arts, Unaizah, Qassim University. Respondents' frequencies of use of slang were collected through a pilot-test. In the form of multiple choices, the instrument consisted of 48 items on slang. Respondents were asked to record their level of use of these items to determine whether they were familiar with the slang and whether they used the slang in their use of English. The respondents were computed through SPSS.

\subsection{Participants}

The participants in the study were 71, (46 level seven and 25 level eight) Bachelor of English Language at Unaizah College of Sciences and Arts, Qassim University, during the academic year of 2019/2020. The participants of this study were all females.

\subsection{Statistical Analysis}

All the data obtained from the study was analyzed using the Statistical Package for Social Sciences (SPSS).Each respondent was presented with 48 items, where each item had for options from "a-d". From those options, only one of them was the correct answer. The correct answers for each item equal one and zero for incorrect answer. Frequency analysis was done to show the occurrence of valid cases "N" which was controlled closely, their mean, median and standard deviation was observed to make sure all cases are analyzed correctly. In addition, the attempts were made (the sum) to show the most and the least familiar slangs.

\subsection{Procedure}

To investigate the familiarity of internet slang among EFL female learners, the following procedures were followed:

a) Selecting appropriate internet slangs (acronyms and abbreviations) to be used in the test.

b) Designing and validating a pilot-test.

c) Selecting the sample and assigning groups.

d) Administering the previous tool to a sample of university students (level seven and level eight).

e) Treating the data statistically by using SPSS software.

f) Interpreting the findings of the study. 


\section{Results and Discussion}

The following sections discuss the frequencies of the correct meaning of slang by the Respondents

Table (1) Respondents' frequencies of the correct meaning of slang No 1-48

\begin{tabular}{|l|l|}
\hline \multicolumn{1}{|c|}{ Valid } & 61 \\
Missing & 0 \\
Mean & 22.70 \\
Median & 23.00 \\
Std. Deviation & 8.699 \\
Minimum & 4 \\
Maximum & 44 \\
\hline
\end{tabular}

As indicated in Table 1, results of the slang test demonstrated that the mean of participants' overall knowledge of Internet slang was $(M=22.70, S D=8.69)$. As the maximum score of the whole test was 44 , this overall knowledge test score could be considered moderately low. The standard deviation $(S D=8.69)$ showed a reasonable spread of the participants' scores around the mean. Based on the notion of the normal curve, the scores fell within two standard deviations above and below the mean; specifically, between the scores 4 and 44 . This clearly shows that few students were able to gain a score as high as 44 (only one) and few others obtained a score as low as 4 . The test results demonstrated that students' knowledge of Internet slang was moderately limited. Consequently, one can conclude that students are not familiar with the Internet slang.

The results also revealed that some of the internet slang, acronyms and abbreviations, are popular among EFL female learner.

The following tables 3-9 show that clearly.

Table (2) Respondents' frequencies of the correct meaning of slang No 1-7

\begin{tabular}{|l|l|l|l|l|l|l|l|}
\hline & \multicolumn{1}{|c|}{ LOL } & BTW & \multicolumn{1}{|c|}{ IMO } & goat & \multicolumn{1}{|c|}{ FIT } & DM & RT \\
\hline Meaning & $\begin{array}{c}\text { Lough Out } \\
\text { Loud }\end{array}$ & $\begin{array}{c}\text { By The } \\
\text { Way }\end{array}$ & $\begin{array}{c}\text { In My } \\
\text { Opinion }\end{array}$ & $\begin{array}{c}\text { greatest } \\
\text { of all } \\
\text { time }\end{array}$ & $\begin{array}{c}\text { Its short } \\
\text { for } \\
\text { 'outfit' }\end{array}$ & $\begin{array}{c}\text { Direct } \\
\text { message }\end{array}$ & Re-twee \\
\hline Mean & .95 & .93 & .74 & .34 & .62 & .97 & .92 \\
Median & 1.00 & 1.00 & 1.00 & .00 & 1.00 & 1.00 & 1.00 \\
Std. Deviation & .218 & .250 & .444 & .479 & .489 & .180 & .277 \\
Sum & 58 & 57 & 45 & 21 & 38 & 59 & 56 \\
\hline
\end{tabular}


Table (3) Respondents' frequencies of the correct meaning of slang No 8-14

\begin{tabular}{|l|l|l|l|l|l|l|l|}
\hline & AMA & \multicolumn{1}{|c|}{ MEME } & TBH & IMHO & TL;DR & NSFW & \multicolumn{1}{c|}{ OTL } \\
\hline Meaning & Anything & $\begin{array}{c}\text { An image or } \\
\text { video with text } \\
\text { that's been } \\
\text { modified over } \\
\text { and over again }\end{array}$ & $\begin{array}{c}\text { To be } \\
\text { honest }\end{array}$ & $\begin{array}{c}\text { In my } \\
\text { humble } \\
\text { opinion }\end{array}$ & $\begin{array}{c}\text { Too } \\
\text { long; } \\
\text { didn't } \\
\text { read }\end{array}$ & $\begin{array}{l}\text { Not safe } \\
\text { for work }\end{array}$ & $\begin{array}{r}\text { It's not an } \\
\text { acronym, } \\
\text { it's an } \\
\text { emoji }\end{array}$ \\
\hline Mean & .66 & .64 & .87 & .43 & .44 & .51 & .20 \\
Median & 1.00 & 1.00 & 1.00 & .00 & .00 & 1.00 & .00 \\
Std. Deviation & 479 & .484 & 340 & .499 & 26 & 27 & 301 \\
Sum & 40 & 39 & 53 & .504 \\
\hline
\end{tabular}

Table (4) Respondents' frequencies of the correct meaning of slang No 15-21

\begin{tabular}{|l|l|l|l|l|l|l|l|}
\hline & IRL & DIKY & SMH & \multicolumn{1}{c|}{ OP } & TIL & \multicolumn{1}{|c|}{ SMOL } & \multicolumn{1}{|c|}{ JSYK } \\
\hline Meaning & $\begin{array}{c}\text { In real } \\
\text { life }\end{array}$ & $\begin{array}{c}\text { Do I } \\
\text { know } \\
\text { you }\end{array}$ & $\begin{array}{c}\text { Shaking } \\
\text { my head }\end{array}$ & $\begin{array}{c}\text { Origina } \\
\text { poster }\end{array}$ & $\begin{array}{c}\text { Today I } \\
\text { learned }\end{array}$ & $\begin{array}{c}\text { Anything } \\
\text { small and } \\
\text { cute }\end{array}$ & $\begin{array}{c}\text { Just so you } \\
\text { know }\end{array}$ \\
\hline Mean & .59 & .67 & .38 & .28 & .16 & .46 & .31 \\
Median & 1.00 & 1.00 & .00 & .00 & .00 & .00 & .00 \\
Std. Deviation & .496 & .473 & .489 & .452 & .373 & .502 & .467 \\
Sum & 36 & 41 & 23 & 17 & 10 & 28 & 19 \\
\hline
\end{tabular}

Table (5) Respondents' frequencies of the correct meaning of slang No 22-28

\begin{tabular}{|l|l|l|l|l|l|l|l|}
\hline & MFW & BRB & hmu & 182 & WTTP & \multicolumn{1}{|c|}{99} & (L)MIRL \\
\hline Meaning & $\begin{array}{c}\text { My face } \\
\text { when }\end{array}$ & $\begin{array}{c}\text { Be } \\
\text { Right } \\
\text { Back }\end{array}$ & $\begin{array}{c}\text { Hit me } \\
\text { up }\end{array}$ & $\begin{array}{c}\text { I hate } \\
\text { you }\end{array}$ & $\begin{array}{c}\text { Want to } \\
\text { trade } \\
\text { pictures }\end{array}$ & $\begin{array}{c}\text { Parent } \\
\text { stopped } \\
\text { watching }\end{array}$ & $\begin{array}{l}\text { Let's meet } \\
\text { in real life }\end{array}$ \\
\hline Mean & .28 & .87 & .30 & .43 & .21 & .03 & .46 \\
Median & .00 & 1.00 & .00 & .00 & .00 & .00 & .00 \\
Std. Deviation & .452 & .340 & .460 & .499 & .413 & .180 & .502 \\
Sum & 17 & 53 & 18 & 26 & 13 & 2 & 28 \\
\hline
\end{tabular}


Table (6) Respondents' frequencies of the correct meaning of slang No 29-35

\begin{tabular}{|l|l|l|l|l|l|l|l|}
\hline & GTG & TTYL & LMK & Bae & YOLO & ICYMI & \multicolumn{1}{|c|}{ TBT } \\
\hline \multirow{2}{*}{ Meaning } & $\begin{array}{c}\text { Got To } \\
\text { Go }\end{array}$ & $\begin{array}{c}\text { Talk To } \\
\text { You } \\
\text { Later }\end{array}$ & $\begin{array}{c}\text { Let Me } \\
\text { Know }\end{array}$ & $\begin{array}{c}\text { Before } \\
\text { Anyone } \\
\text { Else }\end{array}$ & $\begin{array}{c}\text { You } \\
\text { Only } \\
\text { Live } \\
\text { Once }\end{array}$ & $\begin{array}{c}\text { In Case } \\
\text { You } \\
\text { Missed }\end{array}$ & $\begin{array}{c}\text { Throwback } \\
\text { Thursday }\end{array}$ \\
\hline Mean & .39 & .77 & .74 & .30 & .62 & .28 & .28 \\
Median & .00 & 1.00 & 1.00 & .00 & 1.00 & .00 & .00 \\
Std. Deviation & .493 & .424 & .444 & .460 & .489 & .452 & .452 \\
Sum & 24 & 47 & 45 & 18 & 38 & 17 & 17 \\
\hline
\end{tabular}

Table (7) Respondents' frequencies of the correct meaning of slang No 36-42

\begin{tabular}{|l|l|l|l|l|l|l|l|}
\hline & \multicolumn{1}{|c|}{ L } & \multicolumn{1}{c|}{ wbu } & \multicolumn{1}{c|}{ rofl } & FTW & FWIW & \multicolumn{1}{c|}{ KML } & \multicolumn{1}{c|}{ OH } \\
\hline Meaning & Loss & $\begin{array}{l}\text { What } \\
\text { about } \\
\text { you }\end{array}$ & $\begin{array}{l}\text { Rolling } \\
\text { on th } \\
\text { floor } \\
\text { laughing }\end{array}$ & $\begin{array}{l}\text { For the } \\
\text { win }\end{array}$ & $\begin{array}{l}\text { For } \\
\text { what it' } \\
\text { worth }\end{array}$ & $\begin{array}{l}\text { Killing } \\
\text { myself } \\
\text { laughing }\end{array}$ & Overheard \\
\hline Mean & .20 & .67 & .39 & .20 & .41 & .70 & .08 \\
Median & .00 & 1.00 & .00 & .00 & .00 & 1.00 & .00 \\
Std. Deviation & .401 & .473 & .493 & .401 & .496 & .460 & .277 \\
Sum & 12 & 41 & 24 & 12 & 25 & 43 & 5 \\
\hline
\end{tabular}

Table (8) Respondents' frequencies of the correct meaning of slang No 44-48

\begin{tabular}{|l|l|l|l|l|l|l|}
\hline & FOMO & uwu & soft & DAE & G.O.A.T & Ash \\
\hline Meaning & $\begin{array}{l}\text { Fear of A reaction } \\
\text { missing } \\
\text { out }\end{array}$ & $\begin{array}{l}\text { A genera } \\
\text { to } \\
\text { feeling } \\
\text { cuteness }\end{array}$ & $\begin{array}{l}\text { ove } \\
\text { loves }\end{array}$ & $\begin{array}{l}\text { Greatest } \\
\text { else" } \\
\text { of all time }\end{array}$ & As hell \\
\hline Mean & .34 & .34 & .38 & .33 & .33 & .36 \\
Median & .00 & .00 & .00 & .00 & .00 & .00 \\
Std. Deviation & .479 & .479 & .489 & .473 & .473 & .484 \\
Sum & 21 & 21 & 23 & 20 & 20 & 22 \\
\hline
\end{tabular}

Students are not familiar with internet slang, but still, as the tables (2-8) indicate, some of the abbreviations and acronyms are popular, for example, "LOL"," BTW", "DM" and "RT" are more popular among the learners than "99", "OH", " ICYMI", and "FTW". The students 
recognize that "goat" has the same meaning as "G.O.A.T"; they only differ in the way internet users write them. Some of the abbreviations and acronyms are complicated and have more than one meaning, and the meaning that is being conveyed often needs to be determined by the context. "OTL", for example, has a debatable meaning. The meaning to some is "one true love." To others, the meaning is "out to lunch." Besides, many believe that the meaning is expressing great sadness because when the letters "OTL" are typed together they look like a person crying on their hands and knees. Some students mention that their knowledge of internet slang comes from their exposure to social media.

\section{Conclusions of the Study}

Due to the argument over the familiarity of internet slang among EFL female, the present study attempted to investigate the familiarity of internet slang among EFL female learners.

To realize this aim, a slang achievement test was carried out in the Department of English, College of Sciences and Arts in Unaizah, Qassim University in the second semester of the academic year 2010/2020. After selecting appropriate slang to be used inside the classroom, an achievement test was designed.

The number of the subjects involved in the experiment was 71 undergraduate EFL female learners selected and assigned into two groups randomly. The first group was chosen for the pilot study (The pilot study was administered to 10 students , 4 students from level eight and 6 from level seven, later those students were excluded from the final sample). The second group, final sample, was 61 students, (40 level seven and 21 level eight).

Data obtained through these tests were coded and statistically analyzed using SPSS in order to arrive at reliable results and findings.

After collecting the data, the results indicated that Students' knowledge of internet slang is limited and they are not familiar with internet slang, but still, some of the abbreviation and acronyms are popular among EFL learners.

\section{Recommendations}

Recommendations are made based on the above findings.

1- Internet slang should be taught to students as part of communication courses.

2- Teachers should encourage students to share their knowledge of the internet slang in the communication classes since students' knowledge may vary according to their exposure to the internet, especially social media.

\section{References}

Abu Sa'aleek, A. O. (2015). Internet linguistics: A linguistic analysis of electronic discourse 
as a new variety of language. International Journal of English Linguistics, 5(1), 135-145. http://dx.doi.org/ 10.5539/ijel.v5n1p135

Adams, A. S. (2014). Student perceptions of teacher emoticon usage: the effect on teacher credibility and liking (Doctoral dissertation).

Adeeb, E. (2016). The Net-lingo Abbreviations Delineated in Facebook Language Amongst the Iraqi EFL Learners: A Socio-Pragmatic Analysis. Diyala Journal, 72, 621-637.

\section{Aifan, H. A. (2015). SAUDI STUDENTS'ATTITUDES TOWARD USING SOCIAL} MEDIA TO SUPPORT LEARNING (Doctoral dissertation, University of Kansas).

Al-Kadi, A. M. T., \& Ahmed, R. A. (2018). Evolution of English in the internet age. Indonesian Journal of Applied Linguistics, 7(3), 727-736. http://dx.doi.org/10.17509/ijal.v7i3.9823

Al Shlowiy, A. (2014). Texting abbreviations and language learning. International Journal of Arts \& Sciences, 7(3), 455.

Alshawi, N. A. (2018). The Role of Integrative Motivation in the Acquisition of American English Slang by Saudi Female Undergraduate English Majors. Arab World English Journal (August, 2018) Theses ID, 209. http://dx.doi.org/ 10.24093/awej/th.209

Charkova, K. D. (2007). A language without borders: English slang and Bulgarian learners of English. Language Learning, 367(3), 369-416. https://doi.org/10.1111/j.1467-9922.2007.00420.x

Crystal, D. (2006). Language and the internet. New York, USA: Cambridge University Press.

Crystal, D. (2011). Internet linguistics: A student guide. New York: Routledge.

De Jonge, S., \& Kemp, N. (2012). Text-message abbreviations and language skills in high school and university students. Journal of Research in Reading, 35(1), 49-68. http://dx.doi.org/ 10.1111/j.1467-9817.2010.01466.x

Elsherif, E., \& Nsir, N. (2015). İntroducing slang to English language learners. Ohio Teachers of English to Speakers of Other Languages, 7(3), 6-9.

Gomaa, Y. A. (2015). Saudi Youth Slang Innovations: A Sociolinguistic Approach. International Journal of Linguistics, 3(2), 98-112. http://dx.doi.org/ 10.15640/ijlc.v3n2a10

Kern, R. (2006). Perspectives on technology in learning and teaching languages. Tesol Quarterly, 40(1), 183-210. https://doi.org/10.2307/40264516

Liu, S., Gui, D. Y., \& Zuo, Y. (2019). Good slang or bad slang? Embedding internet slang in $\begin{array}{lllll}\text { persuasive advertising. Frontiers in psychology, } 10, & 1251 .\end{array}$ https://doi.org/10.3389/fpsyg.2019.01251

Martin, Weber, and Burant. (1997). claim that aggressive messages are different from slang when slang is not used with the intent to offend people (cited in Mazer \& Hunt, 2008). 


\section{Al Macrothink}

International Journal of English Language Education

ISSN 2325-0887

2020, Vol. 8, No. 2

Mazer, J. P., \& Hunt, S. K. (2008). "Cool" Communication in the classroom: A preliminary examination of student perceptions of instructor use of positive slang. Qualitative Research Reports in Communication, 9(1), 20 - 28.

Meyerhoff, M. (2011). Introducing sociolinguistics (2nd ed.). London; UK: Routledge.

Michael, C. (2019). BECAUSE INTERNET: UNDERSTANDING THE NEW RULES OF LANGUAGE. Training, Language and Culture, 3(3).

Mokhsin, M., Aziz, A. A., Hamidi, S. R., Lokman, A. M., \& Halim, H. A. (2016). Impact of using abbreviation and homophone words in social networking amongst malaysian youth. Advanced Science Letters, 22(5-6), 1260-1264.

Namvar, F., \& Ibrahim, N. (2014). Popularity and familiarity of slang among ESL students. Journal of Applied Sciences, 14(24), 3585-3590. https://doi.org/10.3923/jas.2014.3585.3590

Pradianti, W. (2013). The use of slang words among Junior High School students in everyday conversation (A case study in the ninth grade students of a Junior High School in Bandung). Passage, 1(1), 87-98.

Tomoh, B. (2018). EFFECT OF SLANG ON STUDENTS LANGUAGE AND WRITING. Retrived from https://lifelearners.ng/effect-of-slang-on-students-language-and-writing/ (June $3,2020)$

Wei, M. (2010). Internet slang used by online Japanese anime fans. CH AND PUBLISHING, 91.

Xu, H., \& McAlpine, J. (2008). Anglophone, peewee, two-four... are Canadianisms acquired by ESL learners in Canada?.TESL Canada Journal, 11-30. https://doi.org/10.18806/tesl.v26i1.388

Zabotnova, M. (2017). Acronyms and abbreviations as a part of the internet slang and their role in saving speech efforts in the process of communication in the chatspeaks (Акроніми та абревіатури, як частина мережевого сленгу та їх роль у збереженні мовних ресурсів у процесі спілкування у мережевих чатах)(Акронимы и аббревиатуры, как часть сетевого сленга и их роль в сохранении речевых ресурсов в процессе общения в сетевых чатах). Наукові записки Національного університету «Острозька академія». Серія «Філологічна», (Вип. 67), 26-28.

\section{Dictionaries}

Dictionary, M. W. (2020). Merriam-Webster online dictionary. Retrieved on $10^{\text {th }}$ April 2020.

Dictionary, C. (2020). Cambridge Dictionaries Online. Retrieved on $10^{\text {th }}$ April 2020

\section{Websites}

https://www.magiquiz.com/quiz/how-well-do-you-know-internet-slang/2/ (1-4-2020)

http://home.bt.com/tech-gadgets/internet/social-media/quiz-how-well-do-you-know-internet-s lang-11364135427201 (1-4-2020) 


\section{Macrothink}

https://www.theguardian.com/technology/quiz/2014/aug/07/quiz-internet-slang-bae-how-well -yolo-tbt-mean (1-4-2020)

https://www.businessinsider.com/internet-slang-quiz-2013-11 (1-4-2020)

https://www.buzzfeed.com/evelinamedina/how-old-are-you-based-on-your-slang (1-4-2020)

https://abbreviations.yourdictionary.com/articles/what-is-the-difference-between-an-abbreviat ion-and-an-acroynm.html $\quad(20-5-2020)$

\section{Appendix}

The test, which was used, for this study consisted of 48 items.

\section{How Well Do You Know Internet Slang?}

1. What does 'LOL'
a) *Laugh Out Loud
b) Lollipop
c) Lots Of Love
d) None

2. 'BTW'
a) By Traditional Way
b) Between
c) *By The Way
d) None

3. What does 'IMO' mean?
a) I Am Out
b) *In My Opinion
c) Is My Own
d) None

4. What's a'goat'?
a) An annoying person
b) Someone younger than you
c)*It's an acronym for "greatest of all time"
d) None

\section{Do you know what 'FIT' means?}
a) Failing in Twitter
b) Found in time
c)* It's short for "outfit"
d) None

6. What does the term 'DM' mean?
a) Detailed message
b) Daring message
c)* Direct message
d) None

7. What does 'RT' stand for?
a) Real time
b) *Re-tweet
c) Real Talk
d) None

8. 'AMA', does this acronym sound familiar?
a) Any message already
b) All messages available
c)* Ask me anything
d) None 


\section{Macrothink}

\section{What is a 'MEME?'}
a) A trending article or web page
b)* A video that repeats over and over again
c) An image or video with text that's been modified over and over again
d) None

10. What does 'TBH' stand for?
a) Try to be helpful
b) *To be honest
c) Tomorrow, be happy
d)None

11. What does 'IMHO' stand for?
a)* In my humble opinion
b) It may happen otherwise
c) I may Hulk out
d) None

12. What does' TL;DR' stand for?
a) Too late; didn't read
b) *Too long; didn't read
c)Too lame; didn't read
d) None

13. What does' NSFW' stand for?
a) *Not safe for work
b) Not single for women
c) Not suitable for wimps
d) None

14. What does 'OTL' stand for?
a) On the level
b) *It's not an acronym, it's an emoji
c) Over the line
d) None

15. What does 'IRL' stand for?
a) *In real life
b) I really love
c) I'd rewind life
d) None

16. What does 'DIKY' stand for?
a) Did I kill you?
b)* Do I know you?
c) Did it knock you?
d) None

17. 'SMH'. What does that means?
a)* Shaking my head
b) Stole my handle
c) Stop my heart
d) None

18. 'OP'. What does that mean?
a) Opinion
b)* Original poster
c) Original pairing
d) None

19. What does 'TIL' mean?
a) Until
b) *Today I learned
c) Together in love
d) None

\section{What's 'SMOL'?}
a) Smacking my own lips
b) Show more lyrics
c)* Anything small and cute
d) None

21. What does 'JSYK' stand for?
a) *Just so you know
b) Joking so you know
c) Just so you keep
d) None

\section{What's 'MFW'?}
a) Making friends with
b)* My face when
c) Monday Friday Wednesday
d) None 


\section{What does 'BRB' mean?}
a) Bright Bulb
b) Big Red Button
c) *Be Right Back
d) None

\section{What does'hmu'mean?}
a) *Hit me up
b) Hold me up
c) Hang me up
d) None

25. The number ' 182 ' means....
a)*I hate you
b)I'm thinking of ...
c)Hit the Bullseye with two darts remaining
d) Don't blink, I'll be right back

\section{6. 'WTTP'. What does it mean?}
a) Will they talk privately?
b) Won't tell the parents?
c)*Want to trade pictures?
d) What's up?

27. The number '99' means....
a) Problems
b) Almost $100 \%$ certain
c) *Parent stopped watching
d) Being flak

28. (L) MIRL
a) *Let's meet in real life
b)Like making it really loud
c) Look, Mum is rolling laughing
d)Literally, my imagination really loves. ... .

29. 'GTG'
a) Get Together
b) Girl To Girl
c) *Got To Go
d) None

30. 'TTYL'
a) *Talk To You Later
b) Talk To Your Listener
c)Teach Them Your Lessons
d) None

\section{What does 'LMK' mean?}
a) *Let Me Know
b) Love My King
c) Leave Me Knowing
d) None

\section{What does 'Bae' mean?}
a) By An Eternity
b)* Before Anyone Else
c) Back After Eating
d) None

33. What does 'YOLO' mean?
a) You Own Life Once
b)*You Only Live Once
c)You Only Love Once
d) None

\section{What does 'ICYMI' mean?}
a) In Case You Make It
b) In Case You're Mean and Irritating
c) *In Case You Missed It
d)None

35. What does 'TBT' mean?
a)* Throwback Thursday
b) Think Back Then
c) Take Back That
d) None 


\section{If you took an $\mathrm{L}$, what did you take? A}
a) Look
b) Left
c) * Loss
d) None

37.' wbu'
a) *What about you?
b) Where be you?
c) work bringing me under
d) What's bugging you?

38. 'rofl'
a) Read or fail life
b) Rated on face level
c) Real or fake laughter?
d)*Rolling on the floor laughing

\section{9. 'FTW'}
a) Forget the world!
b) Fly the what!?
c) *For the win.
d) Forget the what?!

\section{0. 'FWIW'}
a) *For what it's worth.
b) Forget where it was.
c) For what it is.
d) For whoever is wondering.

\section{1. 'KML'}
a) Keyhole Markup Language
b) *Killing myself laughing .
c) Keep me looped.
d) None

42. 'OH'
a) Ohio
b) Oh, HEY!
c) Oddly heavy.
d)* Overheard

\section{3. 'FOMO'}
a) Flying over many oceans.
b) *Fear of missing out.
c) Fly over many oceans.
d) None

44. 'uwu'
a) "Where are you?
b) You with us
c) $*$ A reaction to cuteness
d) "Until we understand"

\section{5. ' soft'}
a)" Singled out for trying."
b) "Signing off for today."
c) *A general feeling of love.
d) It just means soft.

\section{6. 'DAE'}
a) *"Does anyone else"
b) "Do anything else"
c) Bae, but it's for dads.
d) An abbreviation of sundae 
47. 'G.O.A.T' means...
a) Going out after this
b)* Greatest of all time
c) Getting out after this
d)None

48. 'Ash' means..
a) *As hell
b) As him
c) As her
d) None

***. Last question - how would you rate this quiz?
A) I loved it!
B) It was pretty okay.
C)Not great...

\section{COMMENT}

\section{Copyright Disclaimer}

Copyright for this article is retained by the author(s), with first publication rights granted to the journal.

This is an open-access article distributed under the terms and conditions of the Creative Commons Attribution license (http://creativecommons.org/licenses/by/3.0/). 